\title{
Characterization of the ageing of an epoxy resin using high temperature nanoindentation
}

\author{
Bruno Passilly ${ }^{*}$ and Romain Delannoy \\ Département Matériaux et Structures, ONERA, 29 avenue de la division Leclerc, 92322 Chatillon Cedex, France
}

Received: 28 September 2018 / Accepted: 10 January 2019

\begin{abstract}
This article aims to understand better the mechanical properties and behavior of organic matrix composite materials under elevated temperature conditions. Two specific specimens of cured RTM6 epoxy resin are tested with DMA analysis: one being unaged and the other one aged for $5000 \mathrm{~h}$ at $130^{\circ} \mathrm{C}$ under ambient air. Anti-plasticization effects seem to occur on aged resin. Series of nano-indentation tests are carried out from the surface to the core of the sample so as to measure gradient properties of the resin, at temperatures up to $150^{\circ} \mathrm{C}$ using a high temperature indentation machine prototype. Thermo-oxidation phenomena involve oxidized layer formation during thermal ageing of the epoxy resin which is characterized through measurements of indentation Young's modulus. After aged treatment, the variation of Young's modulus of the oxidized layer at the surface of the sample is not clearly affected by the increasing test temperature whereas Young's modulus of the core of the sample is decreasing significantly with the temperature test as on unaged epoxy resin. Thus, asymptotic growing of the oxidized layer is then confirmed.
\end{abstract}

Keywords: high temperature / nanoindentation / Young's modulus / ageing / epoxy resin / durability

Résumé. Caractérisation du vieillissement d'une résine époxy par nanoindentation à haute température. Cet article a pour but de mieux comprendre l'évolution des propriétés mécaniques des matrices organiques utilisées dans les matériaux composites à des températures élevées. Deux résines époxy RTM6 sont testées en DMA : l'une non vieillie et l'autre ayant subi un vieillissement de $5000 \mathrm{~h}$ à $130^{\circ} \mathrm{C}$ sous air ambiant. Des effets dus à l'anti-plastification de la résine sont remarqués sur la résine vieillie. Des séries de tests de nanoindentation sont menées de la surface jusqu'au cœur de l'échantillon pour mesurer les gradients de propriétés de la résine, jusqu'à une température de test de $150{ }^{\circ} \mathrm{C}$ en utilisant un moyen prototype de nanoindentation à haute température. Des phénomènes de thermo-oxydation entraînent la formation d'une couche oxydée durant le vieillissement thermique de la résine époxy, qui est caractérisée en mesurant le module d'Young. Après vieillissement, la variation du module d'Young de la couche oxydée n'est pas clairement affectée par l'accroissement de la température alors que le module d'Young du cour de l'échantillon décrôit significativement avec la température comme sur la résine non vieillie. La croissance asymptotique de la couche oxydée est ainsi confirmée.

Mots clés : haute température / nanoindentation / module d'Young / vieillissement / résine époxy / durabilité

\section{Introduction}

The development of the aerospace industry during the last century led to an unrestrained pursuit of better technologies and overall aircraft performances. As such, weightlessness remains today a major challenge for aeronautic companies.

\footnotetext{
* e-mail: bruno.passilly@onera.fr
}

Metal and alloy structures have progressively been replaced by composite materials; especially carbon/epoxy laminates, as they possess interesting specific mechanical properties. However, a better understanding of their durability is necessary to implement these materials further, especially in severe thermal conditions.

To predict mechanical behavior of polymer matrix composite materials at high temperatures, it is necessary to understand the degradation mechanisms occurring during thermal ageing. In presence of oxygen, oxidation of the polymer can take place forming a layer of oxidized epoxy 
TGMDA

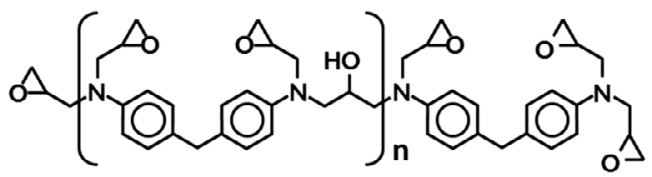

M-MIPA

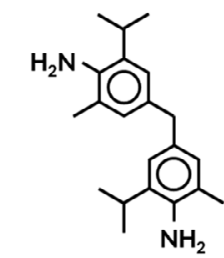

MDEA

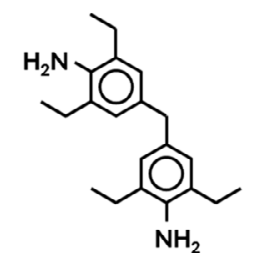

Fig. 1. Chemical components of a RTM6 epoxy resin.

Fig. 1. Composition chimique d'une résine époxy RTM6.

polymer at the surface of the material [1-3]. Mechanical properties degradation during thermal ageing have yet to be thoroughly predicted, specifically at higher temperatures.

This study focuses on an experimental investigation of the evolution of surface mechanical properties of an epoxy resin matrix with thermal ageing. The material behavior will be characterized using high temperature nanoindentation to simulate flight conditions in high temperature regions of the aircraft.

\section{Samples preparation}

Specimens used in the present study are cut from a thermoset RTM6 epoxy resin plate. RTM6 epoxy resin presents a gel temperature of $180^{\circ} \mathrm{C}$ for a gel time of $30 \mathrm{~min}$. The plate is prepared according to a specific polymerization cycle, composed of a $2 \mathrm{~h}$ long cure at $180^{\circ} \mathrm{C}$, followed by a post-cure of $2 \mathrm{~h}$ at $200^{\circ} \mathrm{C}$ to obtain additional crosslinking.

Glass transition of RTM6 resin is about $210^{\circ} \mathrm{C}$ (data produced by Hexcel Corporation).

The epoxy resin is obtained by mixing pre-polymer chains of tetraglicyd methylene dianiline-TGMDA, with two amine hardeners: 4,4'-methylenebis (2-isopropyl-6diethylaniline)-M-MIPA, and 4,4'-methylenebis (2,6diethylaniline)-MDEA as shown in Figure 1.

Crosslinking is mainly obtained by polyaddition between cyclic ether functions of the pre-polymer chains with amine functions of the two hardeners.

Isothermal ageing is carried out on the monolithic epoxy samples at $130^{\circ} \mathrm{C}$ in an oven under atmospheric air, for a duration up to $5000 \mathrm{~h}$. Samples are then taken out from the chamber after ageing time, and cut to appropriate dimensions to be positioned in the nanoindentation machine prototype. Specimens were polished down to $0.25 \mu \mathrm{m}$ to get a polished surface to indent on. To avoid any problems of humidity, samples stayed at least $48 \mathrm{~h}$ at $70^{\circ} \mathrm{C}$ before performing any indentation test series. Humidity of the specimen would influence the measured results of mechanical properties and could create plasticization of the polymer [4]. Characterization of the epoxy specimens are carried out at multiple temperatures, up to $150^{\circ} \mathrm{C}$.

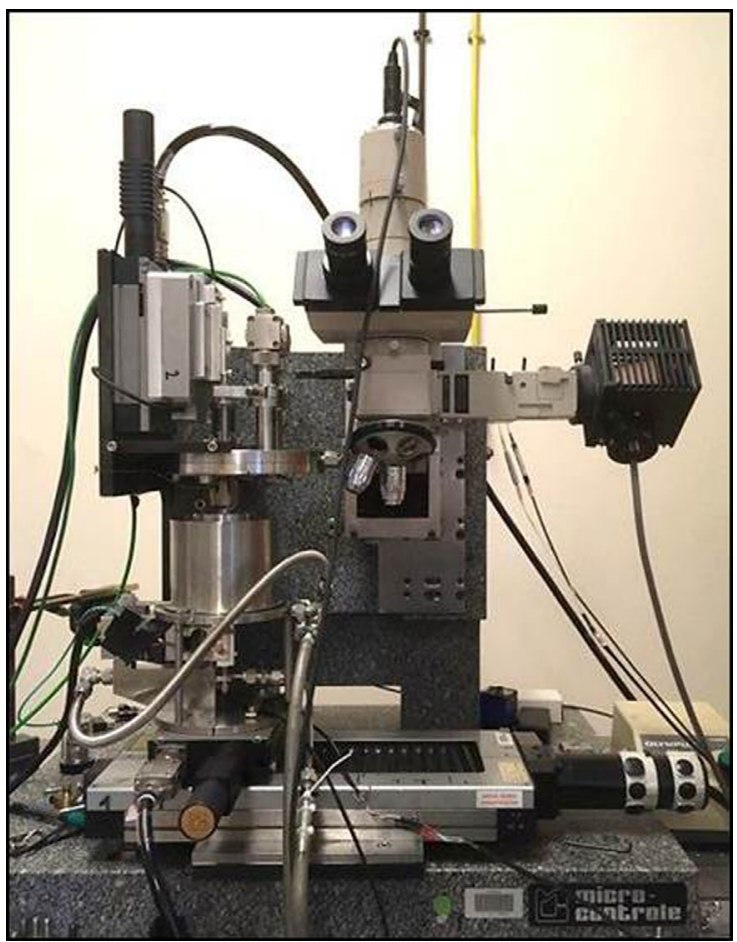

Fig. 2. High temperature nano-indentation machine prototype developed by ONERA.

Fig. 2. Moyen prototype de nanoindentation à haute temperature développé par l'ONERA.

\section{Instrumented high temperature nanoindentation}

\subsection{High temperature nanoindentation apparatus}

The high temperature nanoindentation device shown in Figure 2 used for this study is a prototype developed by ONERA [5]. It uses the same functioning principles as commercial nanoindentation devices. The force $P$ applied onto the sample by the indenter, and the penetration depth $h$, are recorded throughout the indentation tests.

Indenter displacement is controlled by a piezoelectric actuator, and measured by a capacitive displacement transducer. The sample is placed onto a load cell measuring the applied load by the indenter. An additional displacement transducer is placed underneath to measure the load cell deformation. Penetration depth is then determined by substracting the load cell displacement to the indenter displacement.

The indenter and the sample are both heated separately by cylindrical furnaces, thus preventing any thermal gradient and drift upon contact between the indenter and the studied specimen [6]. Temperature is monitored, and studied temperatures can go up to $200^{\circ} \mathrm{C}$.

\subsection{Loading and unloading cycle}

The same loading protocol is used for every nanoindentation test and a typical indentation curve is shown in Figure 3. First, a loading phase is carried out, during 


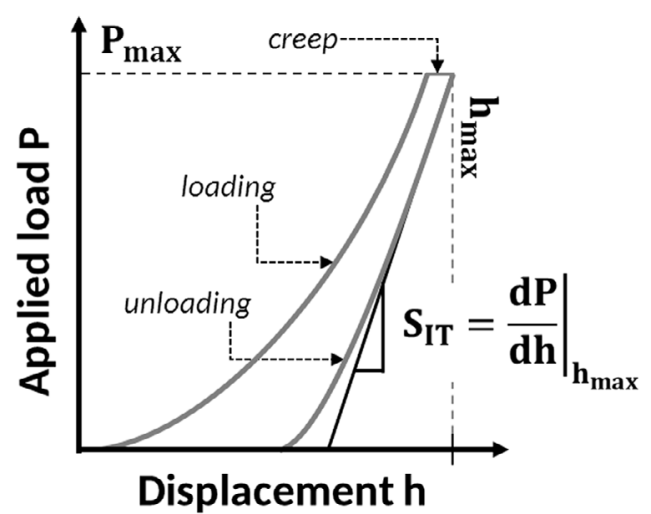

Fig. 3. Schematic graph presenting the multiple phases of the loading cycle during indentation tests.

Fig. 3. Courbe schématique présentant les différentes phases du cycle de chargement pendant les tests d'indentation.

which the indenter is steadily applying a load onto the sample surface. The loading and unloading rate is about $2.5 \mathrm{mN} / \mathrm{s}$. Both elastic and plastic deformations occur, as the hardness impression formed can attest to it.

Once the maximum load of $100 \mathrm{mN}$ is reached, a creep phase is initiated for $200 \mathrm{~s}$, during which the load is maintained at maximum value. This phase is very important for high temperature nanoindentation tests on viscoelastic materials such as RTM6 epoxy resin.

Finally, an unloading phase is carried out until there is no more contact between the indenter and the material. During unloading, the mechanical behavior is assumed to be only elastic, thus facilitating the calculation of indentation hardness and modulus.

\subsection{Determination of the mechanical properties}

A Vickers diamond indenter was used during this study with Young's modulus and Poisson coefficient assumed to be respectively of $E_{i}=1141 \mathrm{GPa}$ and $v_{i}=0.07$. Vickers hardness is defined as the quotient of the maximal applied load $P_{\max }$, expressed in Newton, by the projected indentation area $A_{p}$, expressed in square millimeters:

$$
H_{v}=\frac{P_{\max }}{A_{p}} .
$$

Macroscopic hardness values are usually determined by measuring dimensions of residual indentations imprinted on the sample surface. In indentation, pile-up and sink-in effects are usually studied to be taken into account or not [7] (Fig. 4).

The method introduced in 1992 by Oliver and Pharr [8] is used to determine indentation hardness $H_{I T}$ and modulus $E_{I T}$ using unloading measurements during indentation tests. As such, pile-up of the material is not taken into account for the further calculations because this effect has not been observed by scanning electron microscope. It would be interesting to use in situ high temperature nanoindentation measurements by SEM in order to describe the behavior of the indented sample during the indentation test [9].

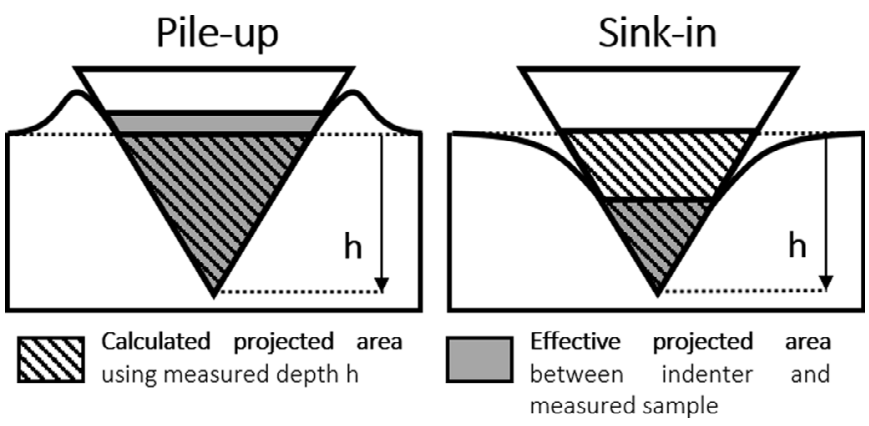

Fig. 4. Pile-up and sink-in phenomena occurring around the indenter tip during indentation loading.

Fig. 4. Phénomènes de pile-up et de sink-in intervenant autour de l'indenteur pendant l'essai d'indentation au chargement.

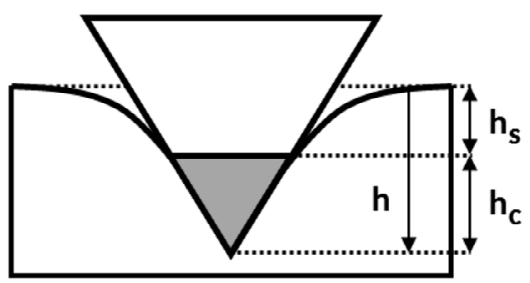

Fig. 5. Schematic representation of a section during indentation.

Fig. 5. Représentation schématique de la section pendant un essai d'indentation.

The profile of the contact geometry around the indenter is described in Figure 5. A few quantities are defined: the sink-in displacement of the surface at the contact perimeter, $h_{s}$, and the effective contact depth of the indenter into the material, $h_{c}$. Maximum displacement $h_{\max }$ can be then defined by using these quantities:

$$
h_{\max }=h_{s_{\max }}+h_{c_{\max }} .
$$

It is assumed the pyramidal tip punch behavior can be modeled by a conical indenter with a half-included angle of $70.3^{\circ}$. Models $[10,11]$ show the amount of sink-in displacement around the tip is calculated using the applied loading $P_{\max }$, and the indentation unloading stiffness $S_{I T}$ :

$$
h_{s_{\max }}=\varepsilon \frac{P_{\max }}{S_{\mathrm{IT}}}
$$

where $\varepsilon$ is a geometric constant depending on the indenter used for the study: $\varepsilon=0.72$ for a conical punch, $\varepsilon=1$ for a flat punch, and $\varepsilon=0.75$ for a paraboloid of revolution. The standard value of $\varepsilon=0.72$ is used for the further calculations.

Using equation (3) to approximate the sink-in displacement of the contact periphery around the Vickers tip, the contact depth at maximum load $h_{c_{\max }}$ can be determined with equation (2):

$$
h_{c_{\max }}=h_{\max }-\varepsilon \frac{P_{\max }}{S_{\mathrm{IT}}} .
$$




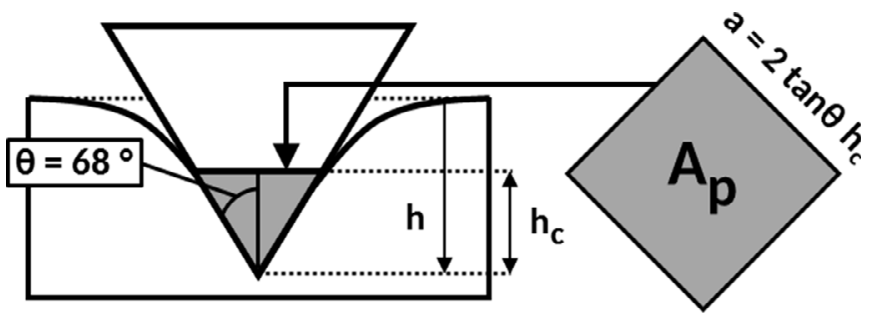

Fig. 6. Schematic representation of the Vickers indenter geometry.

Fig. 6. Représentation schématique de la géométrie de l'indenteur Vickers.

Projected contact area $A_{P \max }$ described in Figure 6, at maximum load contact depth can be then determined using standard geometry of Vickers indenter tip, with the halfincluded angle of the pyramid $\theta=68^{\circ}$ :

$$
A_{P \max }=4 \cdot \tan ^{2} \theta \cdot\left(h_{\max }-\varepsilon \frac{P_{\max }}{S_{\mathrm{IT}}}\right)^{2} .
$$

Once the contact area is determined, the indentation hardness is then computed using equation (1).

Effective indentation modulus is then acquired using measured unloading stiffness and projected contact area:

$$
S_{\text {IT }}=\frac{2 \beta}{\sqrt{\pi}} E_{\text {eff }} \sqrt{A_{P \max }}
$$

where $\beta$ is a correction factor depending on the geometry of the indenter. It plays a major role in measuring precisely indentation modulus and hardness. Although many studies have been carried out to find an accurate value of this factor, $\beta=1.012$ is used as determined by King [12] for a square-base indenter.

As elastic displacement occurs in both indented material and indenter during indentation, the indenter mechanical behavior has to be taken into account to determine the material indentation modulus $E_{\mathrm{IT}}$ :

$$
\frac{1}{E_{\mathrm{eff}}}=\frac{1-v^{2}}{E_{\mathrm{IT}}}+\frac{1-v_{i}^{2}}{E_{i}} .
$$

\section{High temperature mechanical properties of epoxy resin}

\subsection{DMA results}

DMA tests were carried out both on aged and unaged RTM6 epoxy resin samples to characterize global modulus (Fig. 7). The samples have the following dimensions: $45 \mathrm{~mm}$ long, $5 \mathrm{~mm}$ wide, and a thickness of $3 \mathrm{~mm}$.

Storage modulus of the unaged resin decreases from 3.1 to $2.2 \mathrm{GPa}$, while storage modulus of the aged resin decreases from 3.1 to $2.5 \mathrm{GPa}$, when the temperature rises from 30 to $150{ }^{\circ} \mathrm{C}$.

DMA tests show that ageing of the epoxy resin slightly increases global mechanical properties of the sample which is due to oxidized layer formed on the surface of the sample. Young's modulus is higher on aged RTM6 sample, due to anti-plasticization effect which has been studied by different authors [13,14]. Nevertheless, glass transition temperature would be lower for aged sample.

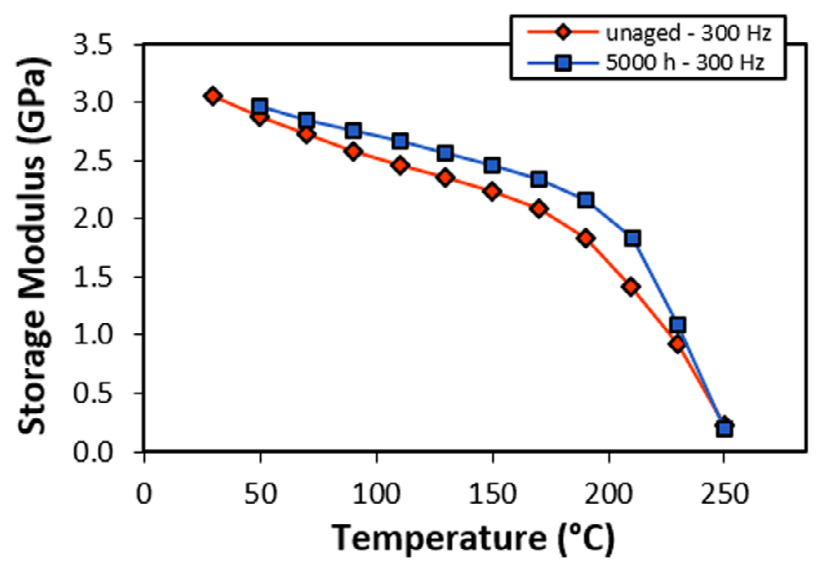

Fig. 7. Dynamic mechanical analysis of aged (for $5000 \mathrm{~h}$ ) and unaged epoxy resin.

Fig. 7. Analyse mécanique dynamique d'une résine vieillie (pendant 5000 h) et non vieillie.

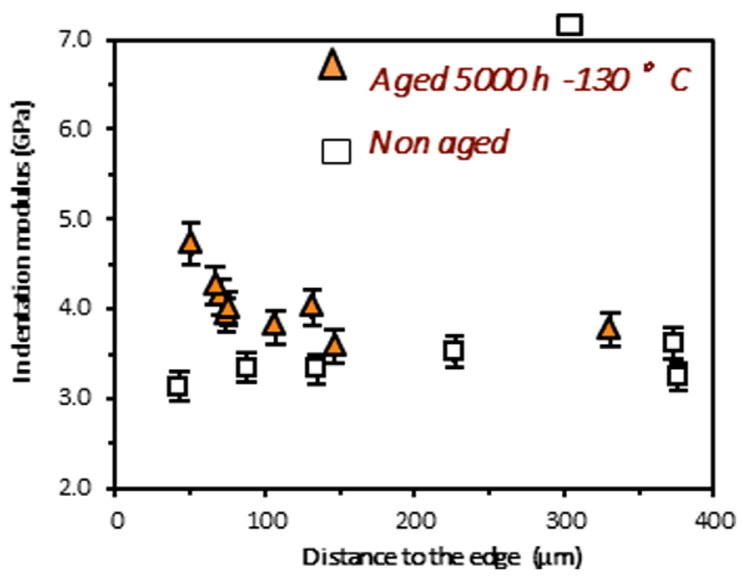

Fig. 8. Indentation modulus characterization from edge to the core of an unaged and aged RTM6 sample.

Fig. 8. Mesure du module par indentation de la surface jusqu'au cœur d'un échantillon de résine RTM6 non vieillie et vieillie.

To explain these global results, nanoindentation tests are performed in order to test local properties on aged and non-aged materials from the edge to the center of the sample from 30 up to $150{ }^{\circ} \mathrm{C}$.

\subsection{Effect of ageing}

Indentation tests on aged and non-aged resins show in Figure 8 that Young's modulus is increasing when the distance to the edge is less than 100 micrometers whereas Young's modulus is constant on the non-ageing resin.

Polymer network becomes more rigid as oxygen diffuses in the sample. This phenomenon of thermo-oxidation affects the external surface of the sample. Thermooxidation effect can also be studied by weight loss measurement under oxidizing atmosphere [15] (Fig. 8). 


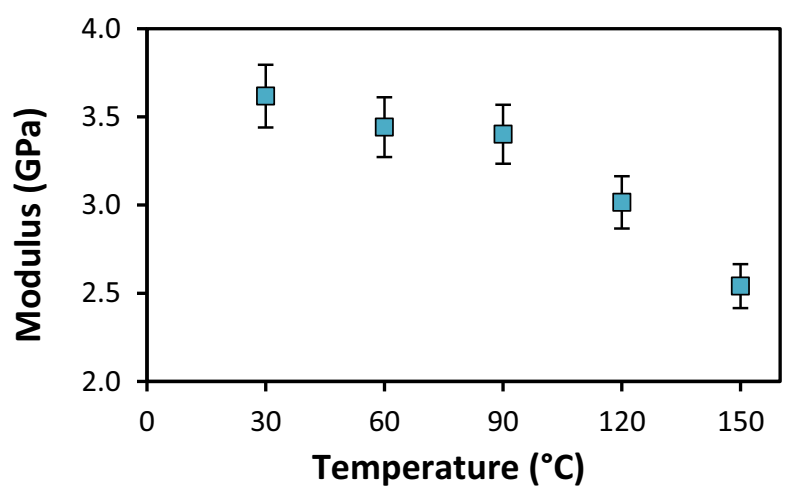

Fig. 9. High temperature indentation modulus characterization of an unaged RTM6 sample.

Fig. 9. Mesure du module par indentation à haute température d'un échantillon de RTM6 non vieilli.

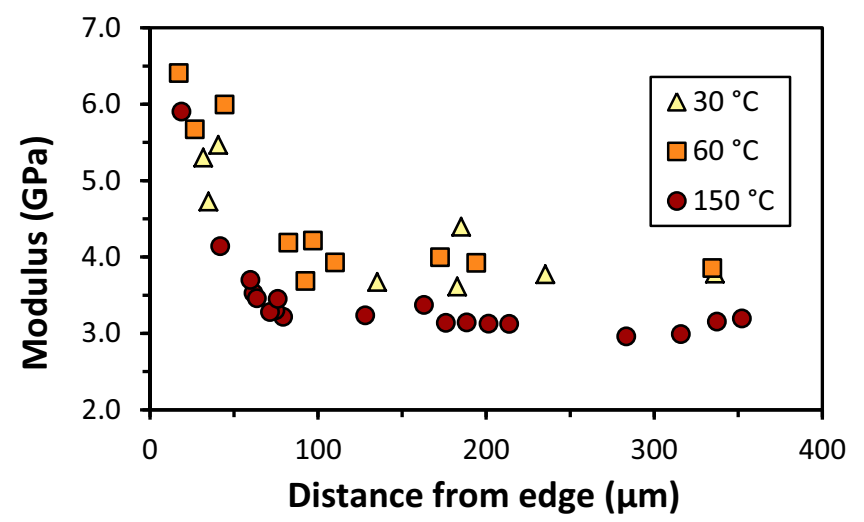

Fig. 10. High temperature indentation modulus characterization of a RTM6 sample aged for $5000 \mathrm{~h}$ at $130^{\circ} \mathrm{C}$.

Fig. 10. Mesure du module par indentation à haute température d'un échantillon de RTM6 vieilli pendant $5000 \mathrm{~h}$ à $130^{\circ} \mathrm{C}$.

\subsection{Unaged resin characterization}

Elevated temperature nanoindentation tests drawn in Figure 9, up to $150^{\circ} \mathrm{C}$ are carried out in the center of an unaged sample of cured RTM6 epoxy resin. Indentation modulus decreases from 3.6 to $2.5 \mathrm{GPa}$ when the temperature rises from 30 to $150{ }^{\circ} \mathrm{C}$.

Under glass transition temperature $\mathrm{Tg}$, viscous effect of polymeric material leads to a decrease of the value of indentation modulus. This effect is due to polymer network degradation, with breakage of polymer chains.

\subsection{Aged resin characterization}

Elevated temperature nanoindentation tests are presented in Figure 10. Tests are then carried out on a RTM6 epoxy resin sample aged for $5000 \mathrm{~h}$ at $130^{\circ} \mathrm{C}$ to characterize local modulus near the edge of the sample. Ageing of the polymer in presence of oxygen creates a layer of oxidized resin on the first $100 \mu \mathrm{m}$ underneath the surface and Young's modulus is decreasing significantly in the thickness of the oxidized layer.
A maximum of $6 \mathrm{GPa}$ is measured near the edge. No significant variation of the modulus in the oxidized layer in the first 100 micrometer thickness is shown when the temperature is increasing. Indentation modulus of the core of the sample, however, decreases to reach $3.0 \mathrm{GPa}$ when the temperature is evolving up to $150{ }^{\circ} \mathrm{C}$.

After ageing, the thickness of the oxidized layer is growing asymptotically and oxidation growing is blocked. Evolution of temperature has no effects on Young's modulus of the oxidized layer because polymer chains do not evolve anymore. In the core of the sample, Young's modulus is decreasing with temperature increasing as observed on non-aged resin, due to degradation of polymer networks.

\section{Conclusion}

This study focuses on an experimental investigation of the evolution of gradient mechanical properties of an epoxy resin matrix with thermal ageing and with temperature test. The variation of Young's modulus of the oxidized layer at the surface of the sample is not clearly affected by the increase in temperature because polymer chains do not evolve anymore, whereas Young's modulus of the core of the sample is decreasing significantly with the temperature due to the viscous effect created by polymer network degradation which is also observed on unaged resin.

These new results show the opportunity of temperature nanoindentation set up to perform tests under severe conditions to determine gradient mechanical properties with a good accuracy of measurement.

\section{References}

1. K. Abdeljaoued, Étude de l'oxydation thermique de la matrice dans les composites fibres de carbones pmr-15, École Nationale Supérieure des Arts et Métiers, Paris, 1999

2. X. Colin, Modélisation cinétique de la thermo-oxydation de matériaux polymères et composites à hautes performances thermomécaniques, École Nationale Supérieure des Arts et Métiers, Paris, 2000

3. M. Minervino, Effets de la thermo oxydation sur le comportement mécanique de composites pour applications aéronautiques, Thèse, ISAE-ENSMA École Nationale Supérieure de Mécanique et d'Aérotechnique, Poitiers, 2014

4. A. Simar, Impact du vieillissement humide sur le comportement d'un composite à matrice organique tissé fabriqué par injection RTM: Mise en évidence d'un couplage entre absorption d'eau et thermo-oxydation de la matrice, Thèse, ISAE-ENSMA École Nationale Supérieure de Mécanique et d'Aéronautique, Poitiers, 2014

5. B. Passilly, M. Bejet, Tip indenting apparatus for testing a block of material, US8181506B2, US Patent, France, May 22, 2012

6. J.M. Wheeler, D.E.J. Armstrong, W. Heinz, R. Schwaiger, High temperature nanoindentation: The state of the art and future challenges, Curr. Opin. Solid State Mater. Sci. 19, 354 (2015) 
7. W.M. Huang, J.F. Su, M.H. Hong, B. Yang, Pile-up and sinkin in micro-indentation of a NiTi shape-memory alloy, Scr. Mater. 53(9), 1055 (2005)

8. W.C. Oliver, G.M. Pharr, An improved technique for determining hardness and elastic modulus using load and displacement sensing indentation experiments, J. Mater. Res. 7(6), 1564 (1992)

9. J.M. Wheeler, J. Michler, Elevated temperature, nanomechanical testing in situ in the scanning electron microscope, Rev. Sci. Instrum. 84, 045103 (2013)

10. J.L. Loubet, J.M. Georges, G. Meille, "Vickers indentation curves of elastoplastic materials", in: P.J. Blau, B.R. Lawn (Eds.), Microindentation Techniques in Materials Science and Engineering, American Society for Testing and Materials STP 889, Philadelphia, 1986, pp. 72-89
11. I.N. Sneddon, The relation between load and penetration on the axisymetric Boussinesq problem for a punch of arbitrary profile, Int. J. Eng. Sci. 3, 47 (1965)

12. R.B. King, Elastic analysis of some punch problems for a layered medium, Int. J. Solids Struct. 23(12), 1657 (1987)

13. L. Audouin, V. Langlois, J. Verdu, J.C.M. De Bruijn, Role of oxygen diffusion in polymer ageing: Kinetic and mechanical aspects, J. Mater. Sci. 29, 569 (1994)

14. X. Colin, J. Verdu, Strategy for studying thermal oxidation of organic matrix composites, Compos. Sci. Technol. 65, 411 (2005)

15. M.C. Lafarie-Frenot, Damage mechanisms induced by cyclic ply-stresses in carbon-epoxy laminates: Environmental effects, Int. J. Fatigue 28, 1202 (2006)

Cite this article as: Bruno Passilly, Romain Delannoy, Characterization of the ageing of an epoxy resin using high temperature nanoindentation, Matériaux \& Techniques 107, 206 (2019) 